so many years ago. My own regret is that, although we were all very familiar with "Modern Analysis", we did not realize, at the time, how progressive he was and how fortunate we were. He had one device, however, which I certainly did appreciate as being modern, and that was his Brunsviga calculating machine which he so kindly taught me to use.

He was always very much aware of students' difficulties during their first year at the University and did much to make the transition as smooth as possible. He often remarked that he was eternally grateful that during his last three years at St. Paul's School, where he was educated, there was an insufficient number of staff to teach him mathematics and consequently he was forced to do much on his own and so became prepared for university style of teaching.

His concern for the well-being of the Mathematical Association was considerable and he did much, behind the scenes, during the difficult financial years to interest influential people in the activities of the Association. He was a regular attender at the Council meetings and frequently made helpful contributions to the discussions.

I am sure that there are many who, like me, owe a great debt of gratitude to Professor Watson for his never failing interest and help, and who will feel that the splendid new Watson Building at Birmingham University will stand as a fitting memorial to a great Mathematician.

6 Cherry Orchard,

WINIFRED A. CoOKe Stoke Poges, Bucks.

\title{
WILLIAM HOPE-JONES
}

\author{
Honorary Member and Vice-President \\ President 1938
}

It might be a delicate problem to name the most distinguished on the roll of the Association's Presidents: but the greatest personality, at least of the past 40 years, was surely Hope-Jones. In a drab age, personality is often equated to eccentricity, but H-J was no eccentric. The title of his presidential address to the Association in 1939, "Simplicity and truthfulness in arithmetic", throws a clear light on his character He placed truth very high on the list of major virtues; "the truth shall make you free", he would say, and for him the basic truths were fundamentally simple. He was not ignorant of the complexities of mathematics or of life, but he believed that these were often self-created, and would resolve into simplicities if only we learned to approach them with simple and humble minds. 
A new-comer to the Council, hearing for the first time that rich, sonorous voice, might perhaps be surprised at the apparent naivété of the speaker, but he would soon learn that H-J's simplicity was neither naive nor artificial, but the direct approach of a sincere mind to a desired truth.

Simplicity, as often in the adult as in the child, seeks for the tangible and the concrete. Few could equal H-J in the apt choice of simple concrete illustrations of abstract ideas, and none excelled him in employing the resources of a robust fancy to clothe these illustrations in a dress which would stamp them on the memory

"How many shares costing $£ 6 \frac{3}{8}$ each can be bought for $£ 300$ ? What is the remainder?" Call them pigs, said H-J, and be a farmer starting out to buy pigs, with $£ 300$ in a wheel-barrow, which, because the price of pigs is in eighths of a pound, he changes into 2400 half-crowns. Each time he buys a pig, he shovels out 51 half-crowns, till he has to stop because he hasn't 51 half-crowns left in the barrow Even the dullest child can see that the remainder is not a fraction of a pig, but a few half-crowns.

To deal with a probability distribution graph, he told* the story of "a new master supervising a row of seven boys whom he does not know by sight. He observes that during the Anthem the middle boy is eating a poached egg, the boy next him is reading a pink newspaper, and the next is consuming rum out of a bottle. Anxious to identify the culprits, he looks at the list of the boys who are supposed to sit in that row. He finds 13 names printed there; call them A, B, C, etc., down to M. Six of these 13 boys are absent, but he has no idea which six. With the evidence at our disposal we have to find the Probability-Distributions of the Poached Egg, the Pink Newspaper, and the Bottle of Rum among the various possible culprits."

Probability, he said, was a bee which buzzed in his bonnet, and he paid full heed to the implications of the theory. When it showed him that if 36 runners enter for a race in which there are 6 prizes, 4 heats of 9 runners with two from each heat in the final will be more likely to give a fair result than 6 heats of 6 runners with one from each heat in the final, he took a large spade and widened the road where the Eton school mile starts, so as to make room for 9 runners. This was typical; H-J was a man who held strongly to his beliefs, and his faith was never slow in expressing itself in works. But he would not reproach those whose beliefs were less firmly held or less actively employed; he would first see his own duty and do it.

His wit, abundantly displayed in the songs he wrote (his verses on Ancient Britons, to the tune of "Men of Harlech", are vastly better than the original) played as happily on mathematics. Witness

* Those who have the reference should see The Mathematical Gazette. XII, No. 171, July 1924, p. 144. 
"Infinity is the place where things happen that don't". Advocatin checks on arithmetical work, he was met with the objection that as we cannot check all methods, why bother to check any: his answes was immediate and devastating; "We can't marry all women, sc why bother to marry any" The Branches of the Association up anc down the country will long remember his addresses, wherein points simply and clearly made were driven home by sharp strokes of wit

To know H-J was a tonic, a corrective to pessimism. The world became a simpler, brighter, happier place when he was present.

Royal Naval College,

T. A. A. Broadben't

Greenwich, S.E. 10.

[The following Oration was delivered At the Funeral by the Reverend L. E. TANNER.]

I want to speak for a few minutes in honour of a good man and a great character, William Hope-Jones.

The sudden death, even of an elderly man, is a great shock to those that are left behind and our warm sympathy goes to his wife and family. Only last week he was riding his bicycle. Only last week he was rebuking me gently but firmly about a remark I made in a sermon about the right literature for the underdeveloped countries. But, if it had been his to select, this I feel would have been his chosen departing. The most striking thing about him was his vigour which never left him. His familiar booming voice which contributed so much to the Mathematics of Eton, later after retirement to Cranleigh and also to the hymns of this church, was a symptom of him. His favourite hymn was Onward Christian Soldiers. This service will end with this hymn, and as you sing it, you will experience a good deal of the man. With vigour went an outstanding alertness. Mentally he did not experience old age. He had a great interest and affection for this church and for the Anglican Church generally, though he could be irritated by it. For a time he was at Ridley Hall, but formularies made him impatient and he did not feel he could be ordained.

But Sunday by Sunday he sat in his pew underneath this pulpit, following the lessons in his Greek Testament, and at both Morning Prayer and Evensong, for recently he had been prevailed upon not to ride his bicycle into Guildford on Sunday mornings to the Society of Friends.

Though I would call him a staunch Christian, I would not describe him as an orthodox one. He was not an orthodox Anglican, nor, I feel, an orthodox Quaker. There was always something of the rebel 